\title{
THE PRODUCTION PROCESS OF TOFU USING RAW MATERIALS TO KEEP QUALITY
}

\author{
Adi Wicaksono and Dian Yuguslavia \\ Narotama University, Surabaya, Indonesia \\ e-mail: adiwicaksono2403@gmail.com
}

\begin{abstract}
ABTRACT
Indonesia is a tropical country where many communities work as farmers by using fertile soil. One of them is soybeans, soybeans can be processed into various foods and beverages, such as tofu, tempe and soybean juice. There are various methods of soybeans process, so that the quality is also various. Quality is the totality of facilities and characteristics of products or services that meet the needs, expressed or implied (Loh, 2001: 35). One of the most favorite foods of Indonesian people is tofu.
\end{abstract}

Keyword: Tofu, Raw Material, Quality

\section{INTRODUCTION}

Indonesia is a tropical country where many communities work as farmers by using fertile soil. One of them is soybeans, soybeans can be processed into various foods and beverages, such as tofu, tempe and soybean juice. There are various methods of soybeans process, so that the quality is also various. Quality is the totality of facilities and characteristics of products or services that meet the needs, expressed or implied (Loh, 2001: 35). One of the most favorite foods of Indonesian people is tofu.

The making of tofu is very easy, so many people make the production of tofu as a source of income. In addition, tofu products is also much preferred of Indonesian people. the tofu is also sold at an affordable price and its available in almost all traditional markets. To choose a good tofu, we must understand how to make the tofu. Therefore this paper is expected to provide the information on how to make tofu, so that the consumed tofu is the good quality tofu.

\section{METHOD}

1. The object used as the subject of discussion is the making of tofu with selected raw materials.

2. The variable used in the study is the making of tofu 
IJTI (International Journal Of Transportation And Infrastructure)

3. The form of information which become the basis for thinking of the study is the number of less qualified tofu, make us looking for selected raw materials to make a quality tofu

\section{DISCUSSION}

Tofu is a food made from the deposition of the soybean juice that is coagulated. Tofu comes from China, as do soy sauce, tauco, bakpau, and meatballs. Tofu is an uptake word of Hokkian, tauhu (hanyu pinyin: doufu) which literally means "fermented soybeans". Tofu is one of the foods that contain many benefits for the body to stay healthy.

Healthy is a balanced and dynamic circumstances between body shape and function and the various factors that affect it (Perkins, 1938).

Untuk membuat tahu kedelai harus melewati beberapa tahap, yaitu

To make the soybean tofu, its must go through several stages, i.e:

\section{A. Selection of quality raw materials}

Good soy has characteristics such as:

1. Peanut seeds are produced from one of the black soils rich in nutrients.

2. Golden and Round-shaped soybean seeds (not Oval)

3. The Size of soybean is very large (100 seeds weight about $22-24$ grams)

\section{B. Washing}

Soybeans should be chosen first, the purpose of this selection is to obtain the clean soybeans and free of dirt to produce quality tofu products. After that, it is inserted into a container with running water so that the dirt comes lifted.

\section{Immersion}

Soak the soybeans in clean water for 8 hours, Try all soybean was sink. In this soaking process the soybean will expand. Then peel the soy skin with squeezing the soybeans in water, then skinned until thesoybean seed look clean.

\section{Milling}

Soybean seed added with hot water in order to deactivate the lipoxygenation enzyme, because this enzyme makes the soy has an unpleasant odor. The milling way is entering the soybean into the the grinding tool until smooth. 


\section{E. Boiling}

This boil aims to inactivate soy antinutrients and increase digestibility. Cook the soy porridge carefully at $70-80$ degrees (usually marked by small bubbles that appear on cooked soybeans). Remember to keep soy not to thicken.

\section{F. Filtering}

Filter the soybean together with tofu stone or vinegar, and stirring slowly. This process will produce precipitated tofu (lumps).

Furthermore, the warm and yellowish soybean extract addeed with a tofu stone or vinegar water till appears the white flakes. This clot lasts for 10 minutes to get the perfect protein.

\section{G. Printing}

Put it in the mold, then put the ballast to press the dregs so that the water content is completely depleted. First of all start with the separation of acidic water or vinegar contained on the sediment by placing the tampah over the precipitate and then pressing it. Then the water will be on the tampah, then taken with a dipper. After that only the protein blob is inserted into the mold where the base is spread over the mori fabric. If the mold has been filled full of protein bolbs, the fold the top of mori fabric and then put the ballast (stone) above the fabric about 3 minutes. Finally its become the tofu, when then its be cut according to customer demand. Its Usually reduced about $5 \times 5 \mathrm{~cm}$.

\section{H. Boiling}

The boiling aims to get the durable tofu, and not easily stale. this process is usually added the turmeric.

\section{CONCLUSION}

\section{Conclusions}

From the description, then we take the conclusion, i.e:

1) Tofu is a soybeans product which is easy to produce and process, even by the home family with simple tools

2) The process of making tofu is through some steps. The steps can be modified in accordance with the needs and can developed continue to get better results. 


\section{Suggestion}

From the description, we would like to convey suggestions such as:

1) The method of making tofu should be improved to get better results

2) Tofu production should be improved as a source of vitamins for the community as well as a source of income

3) Waste from tofu creates an unpleasant odor, so there must be a breakthrough until the waste from this tofu can be utilized.

\section{REFERENCES}

Arimbawa, I Gede, Artaya, I Putu., 2008, Penerapan Metode Korelasi dalam Mengukur Hubungan Antara Customer Relationship dengan Customer Loyalty Pada PT. Antika Raya Surabaya, Jurnal Bisnis dan Manajemen Universitas Negeri Surabaya. Vol. 1, No. 1.

JFX Susanto S., Baktiono, R Agus, Artaya, I Putu., 2018, Optimization of governance model of post-food harest and distribution in msme centers in 5 subdistricts in sidoarjo regency, Journal of Economics, Business \& Accountancy Ventura, Vol. 20, No. 3.

Kastyanto, FT.Widie, 1999, Membuat Tahu. PT Penebar Swadaya. Jakarta

Sarjono, Purbowatiningrum R Dkk. 2006, Profil Kandungan dan Tekstur Tahu Akibat Penambahan Fitat pada Proses Pembuatan Tahu. Jakarta.

Winarno, F.G, Srikandi Fardiaz dan Dedi Fardia, 1980, Pengantar Teknologi Pangan, PT Gramedia, Jakarta

Artaya, I Putu., 2018, Dasar-Dasar Manajemen Operasi dan Produksi, Narotama University Press, Surabaya. 